\title{
ARQUIVAMENTO E CLASSIFICAÇÃO EM “CANHOTA, BAGUNÇA, HIDRELÉTRICAS”, DE NUNO RAMOS
}

Paulo Roberto Barreto Caetano

UFMG

paulo-caetano@ig.com.br

\section{Resumo:}

O texto "Canhota, bagunça, hidrelétricas", de Nuno Ramos, presente no livro Ó, parece trazer uma reflexão acerca dos processos de classificação e possíveis relações que eles estabelecem com uma moldagem da experiência humana. Nessa "história", as cores, os tamanhos (e outros critérios), usados nos arranjos das gavetas e nas categorizações dos arquivos, são tentativas de organizar o caos do entorno. Tais desarranjos são feitos pela espontaneidade desajeitada da mão esquerda (por não possuir o adestramento da direita) e acabam por engendrar uma experiência humana que é fruto, dentre outras coisas, desses procedimentos de ordenação. À luz de Michel Foucault, este artigo, portanto, discute como tais efeitos de ordenação se dão no texto de Ramos.

Palavras-chave: arquivo, classificação, enumeração.

\section{Abstract:}

The text "Canhota, bagunça, hidrelétricas", by Nuno Ramos, from the book Ó, seems to bring a reflection of classification processes and possible relationships they establish with a casting of the human experience. In this "story", colors, sizes (and other criteria) used in the arrangement of drawers and the categorization of files, are attempts to organize the chaos of the surroundings. Such breakdowns are made by the clumsy spontaneity of the left hand (due to the lack of the right hand training) and then engender a human experience that is the result, among other things, of these ordering procedures. In the light of Michel Foucault, this paper therefore discusses how such ordering effects occur in Ramos' text.

Keywords: archive, classification, enumeration. 
No fundo, queremos transformar o grito áspero da matéria e dos formatos num baralho numerado em que as cartas se dispersam apenas para retornar a nós em seguida, em tediosas canastras. ${ }^{1}$

\section{Introdução}

O livro Ó, de Nuno Ramos, foi publicado em 2008 e no ano seguinte arrebatou o prêmio Portugal Telecom. O autor publicou ainda Cujo, em 1993; O pão do corvo, em 2001; O man vidraceiro, em 2010, para citar alguns.

A versatilidade desse compositor, artista plástico e escritor não reside apenas na variedade de suas profissões. Os textos que formam $O$ não permitem os rótulos redutores de "contos" ou "ensaios". Sua amplidão de temas, seu tom que tangencia o ensaio, suas sondagens absurdas colaboram para que fique impossível domá-lo num gênero somente.

Outro aspecto recorrente nessa publicação de 2008 diz respeito a passagens sutis entre os temas abordados: tendo normalmente um arrolamento como título, o enunciador passa de um assunto a outro (por mais díspares que sejam) de uma maneira fluida, que pode passar despercebida ao leitor menos atento.

Em "Canhota, bagunça, hidrelétricas", por exemplo, é possível ver já no título o caráter aparentemente díspar dos temas desse "conto ensaístico". É com muita fluidez que o "narrador" passa das inabilidades da mão canhota até chegar aos acidentes naturais que uma hidrelétrica comporta - sempre tangenciando a bagunça que a mão esquerda faz. Assim, ele relaciona tal ruína a um desejo (às vezes de cunho insólito) de ordenação, cujo objetivo seria se esquivar do caos por meio da organização.

Nessa "história", as cores, os tamanhos (e outros critérios), usados nos arranjos das gavetas e nas categorizações dos arquivos são tentativas de organizar o caos do entorno. Algumas dessas desordens são feitas pela mão esquerda (espontânea e desajeitada), por não possuir o treinamento da direita, e acabam por gerar uma experiência humana que é produto, dentre outras coisas, desses artifícios usuais de ordenação: “Assim, associações, similitudes e combinações imprevistas, a estranha gramática que une uma camada de poeira às listras de um veludo, são substituídos pelo alinhamento cientificista de nossas gavetas." ${ }^{2}$. É devido a sondagens como essa que Ó é chamado de "vasta fantasia antropológica" ou uma "crítica da percepção" ou ainda "uma meditação sobre a ruína". Essa impossibilidade de redução leva José Antonio Pasta a fazer tais brincadeiras na orelha do livro,

\footnotetext{
${ }^{1}$ Ramos, Ó, p. 114 - 5.

${ }^{2}$ Ramos, Ó, p. 115.
} 
questionando-o se tal volume seria uma "tese de doutoramento impossível, apresentada a um departamento de Filosofia do Além”.

Para além das instigantes sondagens que esse texto traz, "Canhota, bagunça, hidrelétricas" permite ao leitor refletir como os critérios taxonômicos influem numa organização do "real”. Assim, gavetas, armários, etc. seriam arquivos que dão visibilidade a esse desejo de organização. Portanto, faz-se relevante discutir como teorias do arquivo são sondadas no mesmo. É importante ainda ressaltar que a publicação de Ó é recente, fato que faz com que haja poucas incursões analíticas sobre o mesmo.

Quanto à linha teórico-crítica deste artigo, o "conto" será abordado tendo em vista as noções de arquivo e as problematizações que envolvem o classificar. Desse modo, será fundamental para a presente análise a leitura de Michel Foucault em As palavras e as coisas acerca de "O idioma analítico de John Wilkins", de Jorge Luis Borges - a partir do qual será pensada a tarefa inglória e obstinada que é a categorização do entorno.

$\mathrm{O}$ texto de Reinaldo Marques intitulado "O arquivo literário como figura epistemológica" será importante para se trabalhar o caráter epistemológico que atravessa o arquivo, pelo fato de haver em "Canhotas..." um exercício de reflexão acerca da experiência humana a partir das classificações e do arquivamento.

Por sua vez, outros textos que trabalham com a questão taxonômica servirão também de suportes teóricos: Maria Esther Maciel em "Poéticas do inclassificável" discute o tratamento que Perec e Greenway têm acerca da impossibilidade da ordenação; já Olga Pombo em "Da classificação dos seres à classificação dos saberes", de maneira um pouco esquemática, trata de categorias dos arquivos que levam à tipificação dos mesmos.

Por fim, o conceito de memória-hábito cunhado por Bergson será importante para se discutir como o suposto caráter espontâneo, idiossincrático da mão esquerda colabora para a instauração de categorias não utilitárias. A partir de Bergson será debatida a relação que o enunciador de "Canhotas..." faz com essa "memória-utilitária" e o classificar pragmático das coisas.

Com tais suportes teóricos, este artigo discutirá como teorias do arquivo são sondadas em "Canhota, bagunça, hidrelétricas", de Nuno Ramos. Para tal tarefa, será necessário analisar as relações entre as taxonomias e os processos de arquivamento.

\section{O rótulo das coisas}


Em As palavras e as coisas, encontra-se uma problematização do ato de classificar, cujo mote é o texto "O idioma analítico de John Wilkins", de Jorge Luis Borges. Michel Foucault, no prefácio de seu livro, comenta sobre o inevitável riso que uma específica enumeração provoca no leitor.

Em seu texto, Borges cita uma classificação oriunda das "remotas páginas" de uma enciclopédia chinesa. Eis a mesma:

(...) os animais se dividem em (a) pertencentes ao imperador, (b) embalsamados, (c) amestrados, (d) leitões, (e) sereias, (f) fabulosos, (g) cães soltos, (h) incluídos nesta classificação, (i) que se agitam como loucos, (j) inumeráveis, (k) desenhados com um finíssimo pincel de pêlo de camelo, (l) etcétera, (m) que acabam de quebrar o vaso, (n) que de longe parecem moscas. ${ }^{3}$

A surpresa que tal enumeração provoca, segundo Foucault, está no lugar e no tempo que ocupa o leitor de Borges. Essa visão que tem o leitor (ocidental, do século XX) faz com que se estranhe tal perspectiva. Para além do desejo impotente de organizar o entorno, as classificações permitem ver um poder - o daquele que as concebe. Assim, as lógicas que as regem são oriundas de uma autoridade, daquele que pôde registrá-la e que concebeu os critérios.

A divisão feita, portanto, é um exercício linguístico de poder que chancela (e inquieta) o que o filósofo francês chama de a "milenar prática do mesmo e do outro". A enumeração acima evidencia um modo de pensar. Ela sugere o limite de Foucault (europeu do século $\mathrm{XX}$ ) e sua impossibilidade de pensar em uma ótica oriental, evidenciando sutilmente o diferente, o outro - a China, lugar que supostamente pouco sofreu com o tempo, resistindo a uma ocidentalização.

Contudo, esse arrolamento do texto de Borges não se trata de encontros insólitos. A matéria com que trabalha a linguagem nesse caso adquire um papel secundário. $O$ foco com que se trabalha é da ordem da linguagem e a organização para qual ela aponta. $\mathrm{O}$ autor de As palavras e as coisas afirma que esses seres arrolados se encontram no não-lugar (imaterial, inexistente) da linguagem. E é esta que permite que "códigos fundamentais de uma cultura"4 instaurem uma ordem. Códigos esses (que regem sua linguagem, seus esquemas perceptivos, suas trocas, suas técnicas, seus valores) que, juntamente com teorias (científicas, filosóficas), reafirmam e explicam o modo como se organiza o entorno.

Portanto, a epistémê, onde os conhecimentos tais como são estão instaurados, manifesta o que o pensador francês chamou de uma história de suas "condições de

\footnotetext{
${ }^{3}$ Borges, Obras completas II, p. 94.

${ }^{4}$ Foucault, As palavras e as coisas, p. XVI.
} 
possibilidades". ${ }^{5}$ Com isso, pode-se dizer que seu modo de ser evidencia seu alcance, tendo em vista como foi concebida. O olhar lançado por Michel F. atém-se aos desdobramentos advindos de tal concepção. A enumeração borgeana se mostra caótica para o olhar ocidental. O enunciador do texto de Borges, ao citá-la, alude a uma epistemologia diferente, provocando o riso naquele que possui um olhar europeu/europeizado. Assim, a divisão citada dessa enciclopédia chinesa sugere uma abordagem do conhecimento e da organização das coisas que se difere da instaurada no ocidente. É a enumeração como um depositário que reflete concepções solidificadas e localizadas.

Em "Da classificação dos seres à classificação dos saberes", Olga Pombo discute alguns aspectos que dão forma às classificações, bem como os métodos existentes de tal prática. Haveria, então, quatro grandes tipos de classificações: ontológica (dos seres), gnosiológica (da ciência), biblioteconômica e informacional. Assim, a autora concilia em seu texto uma visão esquemática com as motivações que pululam as categorizações. A longa, mas necessária, citação que se segue trata dessas complexas tensões de tal prática:

\begin{abstract}
$\mathrm{Na}$ verdade, nada nos parece mais "natural”, óbvio e indiscutível que as classificações dos entes, dos factos e dos acontecimentos que constituem os quadros mentais em que estamos inseridos. Elas constituem os pontos estáveis que nos impedem de rodopiar sem solo, perdidos no inconforto do inominável, da ausência de "idades" ou "geografias". Só elas nos permitem orientar-nos no mundo à nossa volta, estabelecer hábitos, semelhanças e diferenças, reconhecer os lugares, os espaços, os seres, os acontecimentos; ordená-los, agrupá-los, aproximá-los uns dos outros, mantê-los em conjunto ou afastá-los irremediavelmente. ${ }^{6}$
\end{abstract}

Tocando no ponto que abordava Foucault, a autora portuguesa trata da invisível (mas consistente) relação entre a organização de arquivos e a organização do entorno, da "realidade". Segundo a autora, a classificação se inscreve no desejo, e tem a intenção de compreender e ordenar a variedade do "real". Servindo como orientação diante de um real múltiplo e embaralhado, os processos classificatórios atuam como respostas ao obstinado desejo humano de organizar o entorno.

A fim de executar essa organização, usa-se de métodos. Olga P. explicita-os: "1) cada classificação tem por detrás um determinado mecanismo classificador (...) 2) cada classificação persegue uma mais ou menos sistemática multiplicidade de fins que, em última análise, vão determinar a sua estrutura..."7. O primeiro aspecto revela não apenas um caráter pragmático, mas também uma autoridade daquele que opta por seguir um determinado mecanismo de classificação. Por sua vez, o segundo aspecto exemplifica a

\footnotetext{
${ }^{5}$ Foucault, As palavras e as coisas, p. XIX.

${ }^{6}$ Pombo, Leituras, p. 01.

7 Pombo, Leituras, p. 04.
} 
ideia de Foucault acerca da epistémê: é a finalidade e o método (e não o conteúdo propriamente dito) dizendo da categorização. Assim, o método, as escolhas feitas enformam a divisão.

Outros fatores que dão forma às classificações dizem respeito à historicidade e à hierarquia. A primeira se faz presente por meio de um processo de influência (ou assimilação) das classificações que precedem certa divisão. Já a segunda carrega em si uma ideia de "árvore genealógica", por trazer uma "dupla operação": a equivalência e a hierarquia entre os itens/entes. Dessa maneira, critérios como os de Perelman (da presença/ausência de propriedades, e das diferenças específicas) e os de Buffon (dentre eles, das sutis diferenças que revelam um continuísmo e nuances entre as espécies) inseremse nessas perspectivas classificatórias.

Contudo, faz-se necessário expor dois vieses (nem sempre nítidos) que tendem a separar o ato de classificar. A oposição básica entre as classificações das ciências e as da biblioteconomia (e/ou da documentação) está no caráter especulativo da primeira em contraste com os intuitos funcionais da segunda. À luz de Wojciechowski, Pombo reforça esse caráter de cuidadoso exercício mental: para o classificacionista, o que está em questão é a praticidade, a exatidão e a facilidade; já para o filósofo, “o problema da classificação é sempre, em última análise, um problema de adequação, isto é, de conformidade entre a classificação e o domínio de objectos classificados".

É com essa ideia que a autora portuguesa sugere que o ato de classificar seria um exercício filosófico. Para além da apreensão das categorias sutis que o entorno apresenta ao homem, a filosofia poderia contribuir aos classificacionistas com a matéria de reflexão que ela tem, oriunda da experiência gnosiológica e epistemológica. Lidando com questões como, por exemplo, a autoridade, a arbitrariedade, a (im)potência, esse saber se mostraria necessário para o exercício de uma prática complexa como a da organização do entorno.

É Foucault, novamente, que serve de referência para se pensar como tal prática se mostrou intricada há séculos. No capítulo "Classificar", de As palavras e as coisas, o filósofo francês afirma que é um jogo para os historiadores reconstituir os debates em torno da História Natural. Lineu, por exemplo, acreditava que toda a natureza poderia ser categorizada; já Buffon considerava que ela era "demasiado diversa e demasiado rica para ajustar-se num quadro tão rígido". ${ }^{10}$ Mais do que discutir a eficácia das divisões

\footnotetext{
8 Pombo, Leituras, p. 04.

${ }^{9}$ Pombo, Leituras, p. 12.

${ }^{10}$ Foucault, As palavras e as coisas, p. 173.
} 
metodológicas, essa citação aponta para uma discussão sobre a multiplicidade complexa do entorno.

No mesmo capítulo, Michel F. faz um sofisticado panorama sobre como a História Natural lidou com questões como o estudo e a classificação dos seres. Para tal, o pensador francês traz perspectivas de diferentes biólogos, botânicos, etc. O advento do microscópio, a nomeação e descrição do visível, a predominância da teoria da estrutura, a busca pela comprovação da "continuidade" 11 dos seres são tópicos desse capítulo, a fim de se discutir como classificações desse saber lida(ra)m com a apreensão da natureza.

O "caráter" é um conceito trabalhado por Foucault que se mostra valioso para esta discussão acerca do classificar. Isso porque nesse contexto ele é entendido como estrutura escolhida como referência para se estabelecer semelhanças e diferenças. Tal "marco" é importante na discussão do teórico, pois este debate a dificuldade que a História Natural teve ao lidar com a ideia de continuidade das espécies. A identidade era então o resíduo da diferença.

Com isso, a partir do século XVII as designações passam a existir numa relação de diálogo (semelhança e diferença) com todas as outras designações possíveis. Mesmo Buffon tendo afirmado que a continuidade é intricada e fugidia, ${ }^{12}$ caberia à ciência tentar reconstruir o contínuo dos seres.

Para além da evidente dificuldade que se apresenta, é importante ainda mencionar a ideia de imbricação de Michel Adanson, citado pelo autor de As palavras e as coisas. Esse botânico francês do século XVIII trabalhava a noção de natureza como uma mistura estranha (como exemplo, poder-se-ia citar vegetais convivendo com minerais num mesmo habitáculo, ou um inseto convivendo com um peixe) que o acaso juntou. Para Adanson, tal mistura está tão estabelecida que parece até ser uma característica da natureza. Contudo, o mesmo Adanson expõe que tal imbricação tem sua origem no espaço (e não nos seres), pois estes nasceram naquele.

Essa co-habitação de espécies aponta para uma multiplicidade do entorno que dificulta sua divisão pelas ciências naturais. Daí pode-se perceber como se mostra mais plausível a classificação como procedimento de observação das diferenças e das semelhanças visíveis. Classificar é, portanto, fazer uma eleição (arbitrária, limitada) dos critérios que serão relevantes numa seleção.

\footnotetext{
$11 \mathrm{O}$ termo em questão não é sinônimo de evolucionismo. Basicamente, ele diz respeito a uma proximidade que espécies têm entre si. A identidade, como será exposto à frente, será aquilo que, "de resto", difere uma espécie de outra.

12 (Foucault, As palavras e as coisas, p. 202).
} 
Maria Esther Maciel, em "Poéticas do inclassificável", parte do termo atopos para falar do inclassificável em George Perec e em Peter Greenaway. A palavra grega aponta para aquilo que não se situa (não apenas geograficamente, mas também no plano do discurso). As classificações, então, por normalmente não darem conta da diversidade do mundo, acabam por ser uma explicitação daquilo que é atopos. Contudo, tal instabilidade geraria um movimento: “(...) é graças ao que resiste às leis da taxonomia, ou seja, à diferença, que tais sistemas estão sempre em processo de reformulação, revelando sua insuficiência e precariedade." 13 .

A autora comenta que Perec segue um raciocínio semelhante ao que é desenhado no idioma wilkiano, ao criar a categoria "etc.", na qual constariam as coisas inclassificáveis. Dessa nomeação, subtendem-se como tais organizações tendem a esbarrar em itens "não segmentáveis", devido a critérios arbitrários e/ou limitados. Exemplo paradigmático de ser atópico na zoologia citado de Umberto Eco por Maciel é o ornitorrinco, que não se permite ser rotulado apenas como peixe, ave ou quadrúpede.

Apesar das limitações que o classificar enciclopédico carrega em si, é interessante vêlo como uma espécie de modelo de confluência de saberes que marcam o século XXI. É por isso que Maria E. M. afirma que a enciclopédia

(...) destoaria do dicionário, que, por se circunscrever às referências de ordem lingǘstica, tem como função registrar de modo sucinto as propriedades dos termos. A competência enciclopédica, ao contrário, já assume a função de mapear a vida de uma cultura como um sistema de sistemas intersemióticos interligados ${ }^{14}$.

Mesmo com essas limitações, o modelo enciclopédico pode representar uma referência atual para se pensar, por exemplo, no caráter transdisciplinar ou interdisciplinar que os saberes têm. Dessa maneira, procedimentos enciclopédicos diversos (como falar de propriedades físicas, de costumes, e até contar histórias com as magias usadas com eles) apesar de indicar uma diversidade (normalmente) rasa de "abordagens" do objeto, também apontam para a diversidade do entorno, que não se circunscreve em somente um âmbito. A enciclopédia, com sua organização multifacetada, pode oferecer pistas para uma abordagem vária do entorno. Ela seria uma espécie de arquivo de verbetes dotados de diversos saberes (introdutórios, via de regra) que podem ser necessários para se estudar determinado item/ser.

13 (Maciel, Revista Aletria, p. 03).

14 (Maciel, Revista Aletria, p. 06). 
Reinaldo Marques, em "O arquivo literário como figura epistemológica”, propõe a construção de uma história dos arquivos como elemento essencial para se entender a riqueza que se encerra nos acervos de escritores. Em tais lugares, é possível ver, segundo o autor, uma confluência de saberes que não se limitam à esfera literária. A noção de que o discurso histórico pode ser fragmentado, não-contínuo é percebida pela variedade na matéria desses arquivos pessoais:

\begin{abstract}
Ao pensarmos a história dessa perspectiva, estaremos mais aparelhados para lidar com a heterogeneidade dos materiais que compõem os acervos literários manuscritos, datiloscritos, livros, revistas, fotos, correspondências, cartazes, obras de artes plásticas, vídeos, objetos pessoais, mobiliário, etc. -, dotando-os de um caráter híbrido, uma mistura de arquivos documentais, de museu e biblioteca. Estaremos mais preparados ainda para examinar a multiplicidade de discursos - teórico, histórico, crítico, ficcional, memorialístico, biográfico, autobiográfico, epistolar, etc. - que tais acervos mobilizam. ${ }^{15}$
\end{abstract}

Seu caráter híbrido requer, segundo o autor, uma perspectiva histórica que não se pretende totalizante - tal como Benjamin fala nas teses sobre história. As descontinuidades, as rupturas, os jogos de poder (evidenciados, por exemplo, em documentos e monumentos ${ }^{16}$ ) são tensões que evidenciam lugares de fala, com suas construções discursivas e poder de registro.

$\mathrm{O}$ arquivo, então, mostra-se prenhe de tensões que o atravessam, bem como de saberes de naturezas diversas. No caso citado de Marques, saberes como os da física, da química (dentre outros ${ }^{17}$ ) são fundamentais para a preservação do material dos escritores.

A partir de tal olhar (do arquivo como figura epistemológica) se analisará à frente os processos de classificação e arquivamento em um texto de Nuno Ramos. O presente artigo discutirá na próxima seção arquivos que são da ordem da linguagem. Serão verificados então quais seriam os processos de classificação em um “conto" de Ó, bem como o modo como tal texto trabalha com essa prática epistemológica e enformadora da experiência humana.

\title{
3. Uma singularidade que resta
}

\footnotetext{
15 Marques, Revista Aletria, p. 18.

16 cf. LE GOFF, História e memória.

17 Questões complexas (que extrapolam os Estudos Literários e Culturais) transpassam os arquivos de escritores. $\mathrm{Na}$ esfera do direito, por exemplo, pode-se destacar as leis concernentes a doações, aquisição; na biblioteconomia, os processos de catalogação e documentação; na física e química (como citadas), a conservação do material (peso, posição dos livros nas estantes); na arquitetura, a iluminação que esses materiais devem receber, etc..
} 
O caráter enumerativo dos textos de Ó é sugerido já nos títulos desse livro. Dos vinte e cinco "contos", a maior parte deles - dezesseis - tem no título uma enumeração. "Manchas na pele, linguagem", "Galinhas, justiça", "Bonecas russas, lição de teatro" exemplificam alguns dos arrolamentos que dão nome(s) aos textos de Ó. Há de se ressaltar ainda que nessas enumerações não se persegue um paralelismo sintático (os itens perfilados não se restringem a uma categoria gramatical como, por exemplo, o uso exclusivo de substantivos), fato que também aponta para a aparente discrepância dos elementos abordados. Dessa maneira, convivem num mesmo título adjetivos, orações, substantivos, frases nominais, etc., como se pode ver nestes exemplos: "Sinais de um pai sumido, canção", "Esquecer os sonhos, ovas", ou ainda "Tocá-la, engordar, pássaros mortos".

À primeira vista, com tais junções, pode parecer que haverá desconexão entre os assuntos abordados nos textos. Todavia, um dos aspectos que marcam essa publicação de Nuno Ramos é a fluidez com que o "narrador" passa de um tema a outro. Como foi mencionado na introdução deste trabalho, em "Canhota, bagunça, hidrelétricas", apesar de inicialmente díspares, esses assuntos são entrelaçados pelo enunciador de maneira quase imperceptível, trazendo ao leitor diversas considerações que, devido ao caráter analítico, tangenciam o gênero ensaio. ${ }^{18}$

Primeiro elemento arrolado no título, a mão esquerda nesse "conto" é mote para se trabalhar a questão da educação como instrumento podador da individualidade. As atitudes desastradas dessa mão são alçadas a um lugar de espontaneidade que se mostra livre das reações maquinais dos costumes: "Devemos a ela a quota de resguardo de nossas extremidades, que mostram não servir sempre à motricidade fina de atos como enfiar fios numa agulha ou guardar um pequeno brinco na caixinha de veludo". ${ }^{19}$ O termo destacado sugere uma essencialidade, algo aparentemente idiossincrático que não foi perdido na repetição dos atos rotineiros. É essa singularidade preservada que parece restar na canhota. Seu lugar no texto não reside, portanto, só como agenciadora de bagunça e desastres. Ela realizaria uma espécie de "preservação honesta" de certas idiossincrasias:

$\mathrm{Na}$ esquerda as coisas acontecem sempre pela primeira vez, não há como educá-la. Alguma coisa em nós - uma mania, um cacoete, um automatismo da pestana - tem ainda a firmeza de caráter de não aprender nunca, de não passar adiante aquilo que nos ensinam, de permanecer, sisuda e em silêncio, exatamente como sempre foi. Em nossa canhota somos, de alguma forma, recém-paridos, e é isso o que parece catastrófico, sermos ainda livres para derrubar o copo,

\footnotetext{
18 Poder-se-ia pensar ainda que os textos de Ó tangenciassem a prática ensaísta, por não narrarem uma história. Contudo, tal problematização de gêneros requer uma análise por si só - foco distinto do deste artigo. ${ }^{19}$ Ramos, Ó, p. 111. Grifo meu.
} 
livres para cortar o dedo, livres para deixar um objeto no bueiro, como um bebê que engatinha e arrisca a vida por pura curiosidade. ${ }^{20}$

À mão esquerda, portanto, é reservado não só um lugar de espontaneidade, mas de integridade, de uma resistência resoluta, de uma suposta individualidade. Em contrapartida, "Agir pela mão correta [a direita] é repetir o aprendizado morno, a falta de firmeza de quem, afinal, aceita o que lhe ensinam, absorvendo o mandamento alheio". 21 A ideia que aí se encerra se aproxima do conceito de memória-hábito de Henri Bergson, que diz respeito a esquemas de comportamento automático, na resposta a demandas do cotidiano. É graças à memória-hábito que temos o nosso "adestramento cultural", devido às exigências da socialização. Isto é, é graças a ela que sabemos "de cor" escrever, comer educadamente...

Ecléa Bosi, em Memória e sociedade: lembranças de velhos, contrapõe teorias da psicologia social com o viés perceptivo que o filósofo francês dá à instância mnemônica. Para ele, o dia-a-dia, com suas demandas, acaba por influenciar na maneira como os indivíduos lidam com a memória. Desprovido das amarras férreas da labuta ordinária, o homem poderia mergulhar/sondar (em) suas memórias de maneiras distintas das que ele faz ao ser condicionado à rotina prática, "enformadora".

É com tal raciocínio que Ecléa Bosi cita Bergson para dizer que uma vida de contemplação tem íntima ligação com o onírico, o que Bergson chama de uma "memória pura" (a do sonho, da poesia, despregada das amarras citadas), marca de um espírito livre. Por sua vez, a memória-hábito se mostra redutora, pois, além de espoliar a vida contemplativa (por abafar singularidades), é aplicada na ação iminente. Tendo mais tempo livre, o homem poderia perscrutar de maneira mais "cômoda", mais livre o passado que, para o pensador francês, está no inconsciente. O tesouro da memória seria o vasculhar constante do consciente no inconsciente.

A canhota "de" Nuno R. estaria então desprovida desses vínculos empobrecedores dos quais o membro direito se mostra emblemático. O termo "morno" reforça a argumentação desse enunciador que não se priva de escolher a espontaneidade idiossincrática de uma em detrimento do adestramento ordinário da outra.

É com essa argumentação que o enunciador aborda a questão da bagunça e os métodos (simplórios, previsíveis, impessoais) de organização usados pelo homem. Para ele, haveria circunstâncias da vida tão desajustadas, bagunçadas, como uma mão esquerda. Todavia, não é com olhar depreciativo que ele lança luz na desordem, já que esta seria um lugar onde as coisas não estão dispostas de acordo com sua funcionalidade. A desordem

${ }^{20}$ Ramos, Ó, p. 113 - 4.

${ }^{21}$ Ramos, Ó, p. 111. Colchete e grifo meus. 
seria a circunstância em que as coisas conseguem guardar o que haveria de inerente a elas, independentemente de sua utilidade:

\begin{abstract}
A bagunça guarda a potência de que nos afastamos pelo cansaço e pelo trabalho, pela labuta de determinar a posição, a velocidade e o sentido de cada detalhe que nos circunda, pela fadiga de limpar tanta poeira, de corrigir tanta assimetria, de ter tudo sob os olhos e, principalmente, pela necessidade de localizar a cada momento aquilo que buscamos.

Pois se um arco-íris sair pulando de um arquivo morto, nada de espanto, isto é ser organizado, abandonar a placenta que nos unia às coisas, que costumavam cair na posição exata que nos servia. No fundo, queremos transformar o grito áspero da matéria e dos formatos num baralho numerado em que as cartas se dispersam apenas para retornar a nós em seguida, em tediosas canastras. ${ }^{22}$
\end{abstract}

A bagunça, portanto, existiria à revelia dos costumes mecanicistas. O tom de digressão que o "narrador" assume se constrói com sondagens acerca do modo da mão esquerda de se portar, passando por uma espécie de essencialismo que resta naquela mão que não se vende ao modus operandi da praticidade. Esse exercício de reflexão desemboca na (des)organização das coisas e nas escolhas que se faz para organizá-las.

\title{
4. Autores enumerado(re)s: dum item ao todo
}

Se para Foucault a enumeração de Borges aponta para o colapso das categorias, em "Canhota, bagunça, hidrelétricas" o processo de categorização é instrumento de "enformação" do mundo. Daí depreende-se que a ordenação das coisas recebe em Borges um tratamento diverso daquele feito em Ramos. No primeiro, a enumeração caótica é recurso linguístico para se evidenciar a inviável nomeação do entorno, a estranheza e arbitrariedade dos padrões de divisão; no segundo, contudo, as categorizações, por mais inusitadas e caóticas que sejam, refletem um poder idiossincrático de formatação do mundo. Se na enciclopédia chinesa elas revelam uma pulsão de nomeação, de arquivamento, no rigoroso devaneio de $O$, por sua vez, elas dizem respeito à singularidade dos objetos e à manipulação do entorno.

Para o enunciador de "Canhotas...", frequentemente, a verve na organização de gavetas (arquivos, pastas e toda sorte de depositários) é substituída por uma pobre lógica tecnicista: “(...) acabamos utilizando de modo empobrecedor estas divisórias e cartas de um amor proibido, restos de polvilho, cabelos que se infiltram é tudo que deixamos que nossas

\footnotetext{
22 Ramos, Ó, p. 114 - 5.
} 
gavetas recebam" ${ }^{23}$. A segmentação por cores, tamanhos, formatos, funções, etc. poderia, para esse "narrador", ser substituída por uma lógica menos previsível.

É com tal ideia que o enunciador começa a fazer uso de um recurso poético que se mostra recorrente em Ó: a enumeração caótica. Vários são os escritores que lançaram mão desse recurso (Quevedo, Walt Whitman, Jorge Luis Borges, Carlos Drummond de Andrade, dentre outros), com finalidades que passam usualmente pela ideia de apreensão linguística de um entorno que se mostra infinito, multifacetado, e, por isso, irredutível.

Massaud Moisés, em seu Dicionário de termos literários, parte de Leo Spitzer para definir enumeração caótica. Diferentemente da congérie ou "enumeração pura" (que dizem respeito a um arrolamento de itens do mesmo campo semântico), a enumeração caótica "identificase por ser desordenada e por constituir-se de vocábulos pertencentes a classes diferentes". ${ }^{24}$ O autor do dicionário afirma que haveria ainda uma enumeração com um "estilo bazar" que, apesar de apresentar elementos díspares, ainda sugeriria uma lógica, uma "ordem de ideias".

A disparidade dos elementos, portanto, é o aspecto que caracteriza a enumeração caótica. Cabe então verificar alguns exemplos para se discutir o que é feito em "Canhota, bagunça, hidrelétricas". Jorge Luis Borges se mostra paradigmático no uso desse recurso. Como foi mencionado por Foucault, na lista citada de "O idioma analítico de John Wilkins", parece haver uma risível e sofisticada problematização em torno da categorização, com suas arbitrariedades e impotências frente ao real multifacetado.

São vários os exemplos que podem ser destacados do escritor argentino. Por questões de viabilidade metodológica, citar-se-á apenas mais um texto de Borges, para que se problematize o recurso em Nuno R. Em O livro dos seres imaginários, o escritor argentino cria uma espécie de enciclopédia paradoxal: ao mesmo tempo em que ela se mostra infinita, ela é incompleta. Para sustentar tal engenhosidade, no prólogo, Borges ironicamente fala que todos os seres concebidos deveriam fazer parte do volume, e que ele será (supostamente) ampliado de acordo com a contribuição dos leitores:

O nome deste livro justificaria a inclusão do príncipe Hamlet, do ponto, da linha, da superfície, do hipercubo, de todas as palavras genéricas e, talvez, de cada um de nós e da divindade. (...) Um livro desta índole é necessariamente incompleto; cada nova edição é o núcleo de edições futuras, que podem se multiplicar ao infinito.

Convidamos o eventual leitor da Colômbia ou do Paraguai a nos remeter os nomes, a fidedigna descrição e os hábitos mais conspícuos dos monstros locais. ${ }^{25}$

\footnotetext{
${ }^{23}$ Ramos, Ó, p. 115.

${ }^{24}$ Moisés, Dicionário de termos literários, p. 149.

25 Borges, O livro dos seres imaginários p. XI.
} 
Como se vê, a enumeração caótica nesse caso aponta para uma ideia de totalidade. É a linguagem lidando com o infinito, com o inapreensível. Para resolver tal impossibilidade, Jorge Luis B. arrola elementos completamente díspares: uns da geometria, outros da ficção (para citar somente dois). Sob o signo da ironia, o autor trabalha novamente a questão da alteridade, ao dizer que os eventuais leitores colombianos e paraguaios contribuiriam para edições ampliadas dessa enciclopédia monstruosa.

Se o escritor argentino sonda o infinito, Carlos Drummond de Andrade, por sua vez, parece lidar com uma questão um pouco diferente em suas enumerações. Maria Esther Maciel, em "As ironias da ordem em Carlos Drummond de Andrade e em Fernando Pessoa", comenta acerca desse recurso linguístico que pode ter influência do itabirano em Nuno Ramos. Para a autora, a ordenação revela tentativas de compreensão e de controle:

(...) os sistemas de organização das coisas e do conhecimento - não obstante atendam à necessidade humana de dar sentido à multiplicidade e ao caos do mundo - são também mecanismos legitimados pela lógica burocrática do mundo moderno e contemporâneo, com a função de ordenar, controlar, hierarquizar, e rotular nossa vida cotidiana. ${ }^{26}$

Para Maria Esther M., há vários poemas de Drummond que usam da enumeração como organização. Ou ainda que extrapolam isso, fazendo com que o lugar burocrático do inventário seja deslocado para a esfera da invenção pelo humor, pelo disparate, etc. com que a enumeração é feita. No caso de Drummond, parece haver uma caracterização que se faz com a riqueza do absurdo lírico: personagens, contextos, parecem ser caracterizados (não num sentido preciso, limitado do termo), como se vê nesse trecho de "Nosso tempo", poema de $A$ rosa do povo:

IV

(...) É tempo de cortinas pardas, / de céu neutro, política / na maçã, no santo, no gozo, / amor e desamor, cólera / branda, gim com água tônica, / olhos pintados, / dentes de vidro, grotesca língua torcida. / A isso chamamos: balanço. (...)

VIII

O poeta / declina de toda responsabilidade / na marcha do mundo capitalista / e com suas palavras, intuições, símbolos e outras armas / promete ajudar / a destruí-lo / como uma pedreira, uma floresta, / um verme. ${ }^{27}$

As enumerações caóticas acima convergem para essa perspectiva de caracterização. Vê-se, portanto, itens que dizem acerca do objeto caracterizado. Na primeira estrofe citada, o tempo é elemento "qualificado" (momento contaminado provavelmente por uma "ressaca pós-guerra", em que metáforas como "cortinas pardas" e "céu neutro"

${ }^{26}$ Maciel, As ironias da ordem, p. 283.

27 Andrade, $A$ rosa do povo, p. 28, 31. 
possivelmente dizem respeito a um clima de suspensão e tensão); já na segunda estrofe, o poeta, em sua missão idealista de ir contra um sistema mercadológico, usa de armas simbólicas (a linguagem, por exemplo).

Assim, tal arrolamento drummondiano atua como uma espécie de arquivo autorreferencial, por falar do poeta e do tempo em que ele está inserido. Maciel diz que se os itens arquivados dizem respeito a quem os arquiva, a seleção e a ordenação são formas de arquivamento da própria existência ${ }^{28}$. Nesses contextos, vê-se que a enumeração caótica é feita por um literário exercício de reflexão. Percebe-se ainda que ela fulguraria como um depositário de elementos discrepantes a fim de tratar da (ou sondar a) complexidade do homem e seu entorno.

Em "Canhota, bagunça, hidrelétricas", os arrolamentos servem para diversos fins. Um deles é para indicar o caráter vário da bagunça, já que esta pode ser vista na "escova de cabelo misturada à de dentes, documentos onde o café derramou, tickets desbotados no bolso da calça lavada, (...) açúcar endurecido, aparelhos eletrônicos ligados sem ninguém perto....". 29

Outro uso da enumeração (que parece ser mais provocador) diz respeito a uma divisão completamente nova das coisas. Assim, em vez de gavetas e arquivos serem divididos por critérios usuais (tais como formato, cores, utilidade de seus itens), eles seriam organizados por padrões insólitos, mais concernentes a quem dividiu (e não à praticidade do manuseio): "Poderíamos guardar nestas mesmas gavetas, em categorias semelhantes às que efetivamente usamos, o apodrecimento do feno, a borra do batom num guardanapo, a morte de uma aldeia, o vírus da tuberculose". ${ }^{30}$ Totalmente insuspeitada, essa nova seriação dialogaria de maneira mais criativa com aspectos da subjetividade de quem a faz, como um complexo jogo: crítico, reflexivo, idiossincrático:

\footnotetext{
Melhor ainda seria chegar um pouco mais longe, produzindo uma alteração na própria estrutura da catalogação, fazendo, por exemplo, com que cada categoria partilhasse, em vez de principal, apenas a mais fugaz e remota das características que procura ordenar. (...)

Ao invés da soma dos objetos destinados a determinado fim, as gavetas trariam, por exemplo, associações de um poente - lanternas, guache rosa, um galo, fósforo, as luzes de uma cidade vista de longe, acendendo pouco a pouco. ${ }^{31}$
}

A lógica aparentemente rarefeita de que se vale essa divisão aponta sutilmente para algo que é maior do que a concepção de um arquivo específico. A indicação no início dessa

\footnotetext{
${ }^{28}$ Maciel, As ironias da ordem, p. 287.

${ }^{29}$ Ramos, Ó, p. 114.

${ }^{30}$ Ramos, Ó, p. 115-6.

31 Ramos, Ó, p. 114.
} 
citação alude a uma mudança na concepção dum modo de ver o entorno (para, então, classificá-lo). Contudo, tal lógica não se entrega facilmente em "Canhota, bagunça, hidrelétricas". Passando pelos desastres do membro esquerdo, o enunciador fala de uma desordem que este provoca, até tocar em duas instâncias de ordenação: uma, a das categorias, já tratadas neste ensaio; a outra, a da hidrelétrica.

A voz desse texto afirma que essa usina seria a categoria do sublime na engenharia, na tecnologia. Ambas então seriam responsáveis pela criação de potencializados "lugares" de impessoalidade: "Não há um átomo de hesitação num viaduto, nenhuma ambiguidade na rodovia (a não ser quando um acidente ocorre), nenhuma risada na terraplanagem." 32. Escondendo um acidente natural enorme (e prévio), a hidrelétrica seria a responsável por domar a água e os demônios que pululam no imaginário sobre ela: “(...) as tripulações perdidas em ilhotas do Pacífico, a extinção virótica das populações nativas (...) os pulmões cheios de água" 33 .

Tal usina, como metonímia da tecnologia, seria o que o enunciador chamou de "empobrecimento poético daquilo que pode estar aprisionado". ${ }^{34}$ Estrangulando um devir, domando uma rica singularidade idiossincrática, a hidrelétrica abafa uma ambiguidade, provocando o "assassinato do possível". Essa "obra" portentosa da engenharia, ao que parece, enforma o entorno, convertendo-o numa única função - o que regula uma série de instâncias da vida. Do contrário, se ela não existisse, talvez, ter-se-ia uma outra lógica:

\footnotetext{
Ou que ao invés de utilizar aviões pudéssemos ser catapultados em colchões de ar até o outro lado do oceano, abraçados a travesseiros de penas de ganso que voassem ainda? Não haverá em nosso grito uma enorme fonte de energia desperdiçada, e será que o mecanismo de nossas pálpebras não dispensaria combustíveis fósseis? E se cuspíssemos para cima? E se não fizéssemos nada? E se acendêssemos lâmpadas com bocejos? ${ }^{35}$
}

A enumeração nesse caso diz respeito à vastidão do que poderia ter sido, caso escolhas outras tivessem sido feitas; caso classificações diferentes (sob outros critérios) tivessem emoldurado a existência. A provocação que parece ocorrer com essa série de perguntas se refere a direcionamentos pautados no pragmático.

Como símbolo da tecnologia, do utilitarismo, a usina se aproxima da mão direita. Ambas apontam para um solapamento: o abafamento da ambiguidade da água, a contenção da inabilidade (idiossincrática e espontânea) da mão esquerda. Esta, com sua suposta "naturalidade desajeitada" faz oposição à artificialidade esterilizante da hidrelétrica e do

\footnotetext{
32 Ramos, Ó, p. 121.

33 Ramos, Ó, p. 122.

${ }^{34}$ Ramos, Ó, p. 123. Grifo do autor.

35 Ramos, Ó, p. 124.
} 
membro direito.

\section{Conclusão}

O texto de Nuno Ramos debatido apresenta temas díspares, mas que parecem se tocar numa linha tênue: a de uma "crítica" da enformação da experiência humana via processos de ordenação. Estes se dariam pelo desejo humano de organização e domínio (seja de gavetas, seja da imprevisibilidade da natureza, contida pela tecnologia). Assim, por mais arbitrários que sejam os critérios da classificação, eles parecem dizer não só da organização do arquivo, parecem dizer do processo de classificação e dos desdobramentos que ele acarreta. "Canhota, bagunça, hidrelétricas", dessa maneira, questiona uma lógica pragmática de organização das coisas.

Nuno Ramos, portanto, inscreve-se no rol de autores que trabalham com a enumeração caótica como mote para se pensar na enformação que a experiência humana adquire a partir dos processos classificatórios. Em contrapartida, o enunciador de "Canhota, bagunça, hidrelétricas" questiona os contornos limitados que regem as classificações, oriundas de um viver pobremente pragmático. Dessa vez não é o oriental que é "estranhado" em sua diferença, mas toda uma concepção existencial que esbarra na dita praticidade.

Dessa maneira, o texto trabalha com o que poderia ter sido, com a “(...) vida inteira, rascunho de uma outra, [que] iria se espalhando, sonsa e bêbada, em avenidas tão estreitas que nem sempre um passo nosso caberia, e toda linha de contorno seria interrompida e torta, descontínua". ${ }^{36}$ Para além de noções como enredo, história, o caráter ficcional de "Canhota, bagunça, hidrelétricas" está atrelado ao seu devaneio analítico.

\section{Referências bibliográficas}

Andrade, Carlos D. A rosa do povo. São Paulo: Círculo do livro, s.d.

Bergson, Henri. Matéria e memória: ensaio sobre a relação do corpo com o espírito. Tradução de Paulo Neves da Silva. São Paulo: Martins Fontes, 1990.

Borges, Jorge Luis. "O idioma analítico de John Wilkins". In: BORGES, Jorge Luis. Obras completas II. São Paulo: Globo, 1999. p. 92-95.

\footnotetext{
${ }^{36}$ Ramos, Ó, p. 112. Colchete meu.
} 
Borges, Jorge Luis. O livro dos seres imaginários. Tradução de Carmen V. C. Lima. Ilustrações de Lussara gruber. - 4ed - Porto Alegre, Rio de Janeiro: Globo, 1985.

Bosi, Ecléa. Memória e sociedade: lembranças de velhos. São Paulo: Companhia das Letras, 1983.

Derrida, Jacques. Mal de arquivo: uma impressão freudiana. Rio de Janeiro: Relume Dumará, 2001.

Foucault, Michel. As palauras e as coisas: uma arqueologia das ciências humanas. Tradução de Salma T. Muchail. 9. ed. São Paulo: Martins Fontes, 2007. (Coleção Tópicos)

Le Goff, Jacques. História e memória. Tradução de Bernardo Leitão, Irene Ferreira, Suzana F. Borges. 5. ed. Campinas, SP: Editora Unicamp, 2003.

Maciel, Maria Esther. As ironias da ordem: coleções, inventários e enciclopédias ficcionais. Belo Horizonte: Editora UFMG, 2009.

Maciel, Maria Esther. "As ironias da ordem. Carlos Drummond de Andrade e Fernando Pessoa". Disponível em www.abralic.org.br/download/revista/Revista Brasileira de Literatura Comparada 09.pdf Acesso em: 17/07/12.

Maciel, Maria Esther. "Poéticas do inclassificável". Revista Aletria - Programa de PósGraduação em Estudos Literários da UFMG, v. 15, p. 155-162, 2008. Disponível em www.letras.ufmg.br/poslit/08_publicacoes_txt/ale_15/ale15_mem.pdf Acesso em: $14 / 07 / 2012$

Marques, Reinaldo. O arquivo literário como figura epistemológica. In Matraga, Rio de Janeiro, v. 21, p.13-23, 2007. Disponível em www.pgletras.uerj.br/matraga/matraga21/arqs/matraga21a01.pdf Acesso em: 16/07/2012

Moisés, Massaud. Dicionário de termos literários. 12 ed. rev. e ampl. - São Paulo: Cultrix, 2004.

Pombo, Olga. "Da classificação dos seres à classificação dos saberes". Leituras - Revista da Biblioteca Nacional de Lisboa, Lisboa, n. 2, p.19-33, 1988.

Ramos, Nuno. “Canhota, bagunça, hidrelétricas”. In: Ó. São Paulo: Iluminuras, 2008. 